\title{
LIKUIDITAS PT INDOFOOD TAHUN 2015-2016
}

\author{
Elfreda Aplonia Lau
}

\author{
University of 17 Agustus 1945 Samarinda \\ J1. Ir. H. Juanda No. 80, 75124, Indonesia \\ lauelfreda@yahoo.com
}

\begin{abstract}
The rise of corporate activities encourages management to work smart and skilled in order to achieve the company's goals effectively and efficiently. Work effectively and efficiently will be unbalanced if not lonely with honesty. Company honesty can be reflected in its ability to meet short-term obligations commonly known as liquidity

This study aims to determine and analyze the liquidity of PT. Indofood in 2015 and 2016 and measure its growth. The theory used in this research is management accounting that focuses on liquidity, current ratio, quick ratio and cash ratio. The hypothesis of this research is hypothesis 1 to 3: Liquidity PT Indofood in 2015 and 2016 get the criteria of rule of thumb, and hypothesis 4 to 6: Liquidity of PT. Indofood in 2016 experienced growth. The analysis tool used is liquidity analysis measured from current ratio, quick ratio and cash ratio.

The results showed that PT. Indofood is able to get its short term obligations in 2015 and 2016 and get the criteria of rule of thumb. Besides, the result of research shows that liquidity of PT. Indofood in 2016 experienced growth compared to liquidity in 2015. The results of this study can be used by stakeholders in deciding to invest in PT. Indofood or otherwise.
\end{abstract}

Keywords: Cash Ratio, Current Ratio, Liquidity, Quick Ratio

\section{PENDAHULUAN}

Maraknya kegiatan dalam

bidang jasa, perdagangan maupun industri mendorong manajemen untuk bekerja cerdas dan terampil agar mencapai tujuan perusahaan secara efektif dan efisien. Bekerja efektif dan efisien akan timpang bila tidak dironai dengan kejujuran. Kejujuran perusahaan dapat tercerminkan dari kemampuannnya memenuhi kewajiban jangka pendek yang lazim dikenal dengan istilah likuiditas. Pihak manapun akan bersedia bermitra dengan perusahaan lainnya terutama dalam menyediakan dana bagi perusahaan bila perusahaan tersebut mampu menunjukkan kesanggupannya dalam memenuhi kewajiban yang segera jatuh tempo atau jangka pendek.

Adapun tujuan dari penelitian ini adalah untuk mengetahui dan menganalisa likuiditas yang diukur dari 
Current Ratio, Quick Ratio dan Cash Ratio PT Indofood tahun 2015 dan 2016 serta memastikan posisi likuiditas berdasarkan rule of thumb dan

\section{KERANGKA TEORITIS}

Teori utama yang melandasi penelitian ini adalah akuntansi manajemen yang berfokus pada Analisis laporan keuangan yang membahas tentang ratio-ratio keuangan. Diantara rasio-rasio keuangan tersebut adalah rasio likuiditas. Rasio inilah yang akan diteliti, diulas dalam penelitian ini.

\section{Laporan keuangan}

Menurut Bernstein(2007:16)

Financial statement analysis is the application of analytical tools technique to general purpose financial statement and related data to drive estimates and inferences useful in business analysis intuition for business decision. Lebih lanjut Tunggal (2000: 22) berpendapat bahwa analisis dan interpretasi laporan keuangan merupakan sebuah proses untuk membantu memecahkan suatu masalah dan sekaligus menjawab masalahmasalah yang timbul di dalam sebuah organisasi atau atau perusahaan yang bertujuan memperoleh laba (profit oriented) maupun organisasi yang tidak membandingkan pertumbuhan antara likuiditas tahun 2016 dengan likuiditas tahun 2015.

bertujuan untuk memperoleh laba(non profit oriented).

Munawir (2004: 2) Laporan keuangan pada dasarnya merupakan hasil dari proses akuntansi yang dapat digunakan sebagai alat untuk berkomunikasi antara data keuangan aktivitas suatu perusahaan dengan pihak-pihak yang berkepentingan dengan data atau aktivitas perusahaan tersebut. Pihak-pihak yang berkepentingan terhadap posisik keuangan maupun perkembangan suatu perusahaan adalah : para pemilik perusahaan, manager perusahaan, para kreditur, bankers, para investor dan pemerintah di mana perusahaan tersebut berdomisili, buruh serta pihakpihak lainnya.

Termaktup dalam Munawir(2004 : 2-4) bawa laporan keuangan bagi pemilik digunakan untuk menilai hasilhasil yang telah dicapai, menilai kemungkinan-kemungkinan hasil yang dicapai di waktu yang akan datang, sehingga dapat menaksir bagian keuntungan yang dapat diterima dan perkembangan harga saham yang dimilikinya. Sementara bagi manajer 
atau pimpinan perusahaan laporan keuangan merupakan alat untuk mempertanggungjawabkan kepada para pemilik perusahaan atas kepercayaan yang telah diberikan kepadanya dan demi kepentingan analisa intern. Laporan keuangan bagi investor, kreditur dan bankers digunakan sebagai untuk mengetahui prospek keuntungan di masa mendatang dan perkembangan perusahaan selanjutnya, untuk mengetahui jaminan investasinya dan untuk mengetahui kondisi kerja atau kondisi keuangan jangka pendek perusahaan tersebut, sehingga dapat menentukan langkah-langkah yang hendak ditempuhnya. Para kreditur dan bankers sebelum memutuskan untuk memberi atau menolak permintaan kredit dari suatu perusahaan perlu mengetahui terlebih dahulu posisi keuangan dari perusahaan yang bersangkutan. Demikian pula pemerintah sangat memerlukan laporan keuangan perusahaan karena selain untuk menentukan besarnya pajak, laporan keuangan dibutuhkan juga oleh Biro Pusat Statistik, Dinas Perindustrian, Perdagangan dan dan Tenaga Kerja sebagai dasar perencanaan pemerintah.

Berdasarkan paparan-paparan tersebut dapat dikatakan bahwa laporan keuangan sangat diperlukan oleh berbagai pihak dalam pengambilam keputusan sesuai tugas, tanggungjawab maupun kepentingannya dalam suatu perusahaan.

\section{Sifat Laporan keuangan}

Laporan keuangan merupakan hasil akhir dari proses akuntansi. Munawir (2004:6) mengetengahkan bahwa laporan keuangan dipersiapkan atau dibuat dengan maksud untuk memberikan gambaran atau laporan kemajuan(Progress Report) secara periodik yang dilakukan pihak manajemen yang bersangkutan. Jadi laporan keuangan adalah bersifat historis serta menyeluruh dan sebagai suatu progress report laporan keuangan terdiri dari data-data yang merupakan hasil dari suatu kombinasi antara : 1 . Fakta yang telah dicatat (recorded fact), 2. Prinsip-prinsip dan kebiasaankebiasaan dalam akuntansi(accounting convention and postulate), 3. Pendapat pribadi (personal judgment).

Secara detail fakta yang telah dicatat berarti bahwa laporan keuangan ini dibuat berdasarkan kejadiankejadian dari catatan akuntansi. Pancatatan tersebut berdasarkan data historis, sehingga laporan keuangan 
tidak dapat mencerminkan posisi keuangan dari suatu perusahaan dalam kondisi perekonomian yang paling akhir. Kemudian yang dimaksud dengan prinsip-prinsip dan kebiasan-kebiasan dalam akuntansi adalah data yang dicatat didasarkan pada prosedur maupun anggapan-anggapan tertentu yang merupakan prinsip-prinsip akuntansi yang lazim(General Accepted Accounting Principles)dengan tujuan untuk memudahkan pencatatan (ekspediensi) atau untuk keseragaman. Sedangkan yang dimaksudkan dengan pendapat pribadi (personal judgment) adalah pertimbangan atau pendapat akuntan atau management perusahaan yang sangat tergantung pada kemampuan atau integritas pembuatnya yang dikombinasikan dengan fakta yang tercatat dan kebiasaan serta dalil-dalil dasar akuntansi yang yang telah disetujui akan digunakan di dalam beberapa hal.

\section{Keterbatasan laporan keuangan}

Munawir (2004: 9)

mengetengahkan keterbatasan laporan keuangan sebagai berikut :

1. Laporan keuangan yang dibuat secara periodic pada dasarnya merupakan interim report(laporan yang dibuat antar waktu tertentu yang sifatnya sementara) dan bukan merupakan laporan yang final.

2. Laporan keuangan menunjukkan angka dalam rupiah yang kelihatannya bersifat pasti dan tepat, tetapi sebenarnya dasar penyusunannya dengan standar nilai yang mungkin berbeda atau berubah-ubah.

3. Laporan keuangan disusun berdasarkan hasil pencatatan transaksi keuangan atau nilai rupiah dari berbagai waktu atau tanggal yang lalu, dimana daya beli (purchasing power) uang tersebut semakin menurun dibandingkan dengan tahun-tahun sebelumnya sehingga kenaikan volume penjualan yang dinyatakan dalam rupiah belum tentu menunjukkan unit

yang dijual semakin besar, mungkin kenaikan itu disebabkan naiknya harga jual barang tersebut.

4. Laporan keuangan tidak dapat mencerminkan berbagai factor yang dapat mempengaruhi posisi keuangan perusahaan karena factor-faktor tersebut tidak dapat dinyatakan dengan satuan uang. 


\section{Likuiditas}

Likuiditas

merupakan

kemampuan perusahaan dalam memenuhi kewajiban jangka pendeknya atau kewajiban yang segera ditagih. Rasio likuiditas (liquidity ratio) oleh Irham Fahmi (2012: 121) didefinisikan sebagai ratio yang digunakan untuk mengukur kemampuan suatu perusahaan dalam memenuhi kewajiban jangka pendeknya secara tepat waktu. Rasio ini sering disebut juga dengan short term liquidity.

Suatu perusahaan dikatakan mempunyai posisi keuangan yang kuat apabila mampu : 1) memenuhi kewajiban -kewajiban nya tepat pada waktunya; yaitu pada waktu ditagih(kewajiban keuangan terhadap pihak ekstern. 2) Memelihara modal kerja yang cukup untuk operasi yang normal(kewajiban keuangan terhadap pihak intern). 3) Membayar bunga dan deviden yang dibutuhkan. 4) memelihara tingkat kredit yang menguntungkan.

Posisi keuangan jangka pendek atau likuiditas oleh Bambang Riyanto dalam Munawir(2004:70) dapat diukur dengan 4 ratio yaitu: Curren ratio, cash ratio, acid tes ratio dan working capital ratio. Ratio yang paling umum digunakan untuk mengukur likuiditas adalah current ratio yaitu perbandingan antara aktiva lancar dan utang lancar yang dinyatakan dalam prosentase. Current ratio $200 \%$ hanya merupakan kebiasaan Irule of thumb dan akan digunakan sebagai titik tolak untuk mengadakan analisis selanjutnya. Current ratio ini menunjukkan tingkat keamanan (margin of safety) kreditur jangka pendek atau kemampuan perusahaan untuk memenuhi utangutang tersebut.Tetapi Current ratio yang tinggi belum tentu menjamin dibayarnya utang perusahaan karena proporsi atau distribusi dari utang lancar yang tidak menguntungkan.

Beberapa faktor yang perlu dipertimbangkan dalam menganalisa current ratio yakni: distribusi atau proporsi dari aktiva lancar, Trend data aktiva lancar dan utang lancar untuk jangka waktu 5 tahun atau lebih, syarat yang diberikan oleh kreditur, present value, kemungkinan perubahan nilai aktiva lancar, perubahan persediaan dalam hubungannya dengan volume penjualan, kebutuhan jumlah modal kerja dimasa yang akan datang, tipe atau jenis perusahaan( Munawir, 2004 : 72-73) 
Acid tes ratio atau Quick ratio merupakan merupakan perbandingan antara total aktiva lancar tanpa persediaan dengan total utang lancar dinyatakan dalam prosentase. Dasar pertimbangan tidak menyertakan persedian dalam perhitungan total aktiva lancar karena persediaan memerlukan waktu yang relative lama untuk direalisisr menjadi uang kas dibandingkan dengan piutang. Rule of thumb dari $\mathrm{QR}=100 \%$. Demikian pula ratio kas(cash ratio) lebih tajam dari Current ratio dan quik ratio karena hanya membandingkan aktiva yang sangat likwid dengan utang lancar. Ratio kas sering dinamakan juga dengan immediate solvency yaitu rasio yang mengukur

kemampuan yang sesungguhnya untuk memenuhi utang-utangnya tepat pada waktunya (Munawir, 2004: 74).

\section{METODE PENELITIAN}

Variabel dan indikator variabel penelitian ini dapat didefinisikan sebagai berikut : Likuiditas merupakan kemampuan PT. Indofood dalam memenuhi kewajiban jangka pendek pada tahun 2015 dan tahun 2016. Likuiditas diukur dari current ratio, acid test ratio dan cash ratio pada tahun 2015 dan tahun 2016. Current ratio yaitu perbandingan antara aktiva lancar PT. Indofood tahun 2015 dan tahun 2016 dengan utang lancar PT. Indofood tahun 2015 dan tahun 2016 yang dinyatakan dalam prosentase. Current ratio 200\% hanya merupakan kebiasaan / rule of thumb. Acid tets ratio atau Quick ratio merupakan merupakan perbandingan antara total aktiva lancar tanpa persediaan dari PT. Indofood tahun 2015 dan tahun 2016 dengan total utang lancar PT. Indofood tahun 2015 dan tahun 2016 dinyatakan dalam prosentase.

Rasio kas sering dinamakan juga dengan immediate solvency yaitu rasio yang mengukur kemampuan yang sesungguhnya dari PT Indofood pada tahun 2015 dan 2016 untuk menutupi utang-utang PT Indofood pada tahun 2015 dan 2016 tepat pada waktunya. Pertumbuhan yaitu ratio yang menunjukkan capaian peningkatan likuiditas PT Indofood pada tahun 2016. Jenis data dalam penelitian ini adalah data sekunder berupa data laporan Posisi keuangan PT. Indofood pada tahun 2015 dan 2016. Data-data ini dihimpun dengan melakukan penelitian kepustakaan/Library Research yaitu data penelitian ini diambil dari IDX tahun 2015 dan 2016. 


\section{Alat Analisis}

Data laporan posisi keuangan tahun 2015 dan 2016 dari PT. Indofood dianalisis dengan menggunakan ratio likuiditas menurut Munawir (2004 : 7274) sebagai berikut :

Current Ratio $=\frac{\text { Akltiva Lancar }}{\text { Hutang Lanear }} \times 100 \%$

Quick Ratio $=\frac{\text { Akltiva Lancar }- \text { Persedioan }}{\text { Hutang Lancar }} \times 100 \%$ Cash Ratio $=\frac{\text { Akltiva Lancar }-(\text { Persedioan }+ \text { Piutang })}{\text { Hutang Lonear }} \times 100 \%$ Rasio Pertumbuhan Current Ratio $=\frac{\text { Current Ratio } 2016 \text { Current Ratio } 2015}{\text { Current Ratio }} \times 100 \%$ Rasio Pertumbuhan Quick Ratio $=\frac{\text { Quick Ratio }_{2016}-\text { Quick Ratio }_{2015}}{\text { Quick Ratio }_{2015}} \times 100 \%$ Rasio Pertumbuhan Cash Ratio $=\frac{\text { Cash Ratio } 2016}{\text { Cosh Ratio }- \text { Cash Ratio } 2015} \times 100 \%$ ANALISIS DAN PEMBAHASAN ANALISIS

Pengukuran Likuiditas dilakukan dengan menggunakan ratio-ratio likuiditas berikut :

Current Ratio $=\frac{\text { Akltiva Lancar }}{\text { Hutang Lancar }} \times 100 \%$ Current Ratio $_{2015}=\frac{R p 13.961 .500 .000 .000}{R p ~ 6.002 .344 .000 .000} \times 100 \%=232,60 \%$ Current Ratio $2016=\frac{R p 15 \cdot 571.362 .000 .000}{R p ~ 6.469 .785 .000 .000} \times 100 \%=240,68 \%$ Quick Ratio $=\frac{\text { Akltiva Lancar }- \text { Persedican }}{\text { Hutang Lancar }} \times 100 \%$ Quick Ratio ${ }_{2015}=\frac{R p 13,961.500,000-\operatorname{Rp} 2.548,835,000,000}{\operatorname{Rp} 6.002,344,000,000} \times 100 \%=190,136 \%$

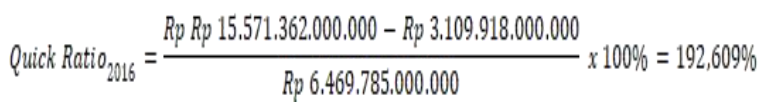

Cash Ratio $=\frac{\text { Akltiva Lancar }-(\text { Persediaan }+ \text { Piutang })}{\text { Hutang Lancar }} \times 100 \%$ Cash Rationo15 $=\frac{\operatorname{Rp} 13.961 .5000 .000-\operatorname{Rp} 5.911 .552 .000 .000}{\operatorname{Rp} 6.002 .344 .000 .000} \times 100 \%=134,13 \%$

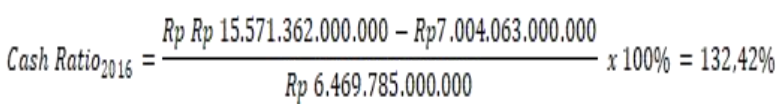
Rasio Pertumbuhan Current Ratio $=\frac{\text { Current Ratio } 2016 \text { - Current Ratio } 2015}{\text { Current Ratio }} \times 100 \%$ Rasio Pertumbuhan Current Ratio $=\frac{240,68-232,60}{232,60} \times 100 \%=3,47 \%$ Rasio Pertumbuhan Quick Ratio $=\frac{\text { Quick Ratio } 2016-\text { Quick Ratio }_{2015}}{\text { Quick Ratio }} \times 10015$ Rasio Pertumbuhan Quick Ratio $=\frac{192,609-190,136}{190,136} \times 100 \%=1,3 \%$ Rasio Pertumbuhan Cash Ratio $=\frac{\text { Cash Ratio } 2016-\text { Cash Ratio }_{2015}}{\text { Cash Ratio }} \times 100 \%$ Rasio Pertumbuhan Cash Ratio $=\frac{132,42-134,13}{134,13} \times 100 \%=-1,275 \%$

\section{Pembahasan}

Berdasarkan hasil analisis ditemukan bahwa Likuiditas PT. Indofood tahun 2015 diukur dari Current Ratio menunjukkan angka sebesar 232,60 \%. Ratio 232,60\% berada diatas rule of thumb atau memenuhi criteria rule of thumb yaitu 200\%. . Ratio ini menunjukkan bahwa setiap Rupiah Utang lancar dibayar dengan Rp2,326 aktiva lancar. Hal ini membuktikan bahwa PT.Indofood mampu melunasi kewajiban jangka 
pendeknya pada tahun 2015. Temuan ini mendukung hipotesis penelitin bahwa Likuiditas PT.Indofood pada tahun 2015 memenuhi criteria rule of thumb.

Likuiditas PT. Indofood tahun 2016 diukur dari Current Ratio menunjukkan angka sebesar 240,68\%. Ratio $240,68 \%$ berada diatas rule of thumb atau memenuhi criteria rule of thumb yaitu 200\%.. Ratio ini menunjukkan bahwa setiap Rupiah Utang lancar dibayar dengan Rp2,4068 aktiva lancar. Hal ini membuktikan bahwa PT.Indofood mampu melunasi kewajiban jangka pendeknya pada tahun 2016. Temuan ini mendukung hipotesis penelitian bahwa Likuiditas PT.Indofood pada tahun 2016 berada diatas rule of thumb.

Likuiditas PT. Indofood tahun 2015 diukur dari Acid Test ratio menunjukkan angka sebesar 190,36 \%. Ratio 190,36\% memenuhi kriteria rule of thumb sebesar 100\%. Ratio ini menunjukkan bahwa setiap Rupiah Utang lancar dibayar dengan Rp1,9036 aktiva lancar tanpa neggunakan nilai persediaan. Hal ini membuktikan bahwa PT.Indofood mampu melunasi kewajiban jangka pendeknya pada tahun 2015. Temuan ini mendukung hipotesis penelitin bahwa Likuiditas PT.Indofood pada tahun 2016 memenuhi kriteria rule of thumb.

Likuiditas PT. Indofood tahun 2016 diukur dari Acid Test ratio menunjukkan angka sebesar 192,60\%. Ratio 192,60\% memenuhi kriteria rule of thumb yaitu $100 \%$ atau $1: 1$. Ratio ini menunjukkan bahwa setiap Rupiah Utang lancar dibayar dengan Rp1,92 aktiva lancar tanpa neggunakan nilai persediaan. Hal ini membuktikan bahwa PT.Indofood mampu melunasi kewajiban jangka pendeknya pada tahun 2016. Temuan ini mendukung hipotesis penelitian bahwa Likuiditas PT.Indofood dinilai dari aspek Quick Ratio atau Acid Test Ratio pada tahun 2016 memenuhi kriteria rule of thumb.

Likuiditas PT. Indofood tahun 2015 diukur dari Cash ratio menunjukkan angka sebesar 134,13\%. Ratio 134,13\% memenuhi kriteria rule of thumb yaitu $100 \%$ atau $1: 1$. Ratio ini menunjukkan bahwa setiap Rupiah Utang lancar dibayar dengan Rp1,3413 aktiva lancar tanpa neggunakan nilai persediaan dan piutang. Hal ini membuktikan bahwa PT.Indofood mampu melunasi kewajiban jangka pendeknya pada tahun 2015. Temuan ini mendukung hipotesis penelitian 
bahwa Likuiditas PT.Indofood dinilai dari aspek Cash ratio pada tahun 2015 memenuhi kriteria rule of thumb.

Likuiditas PT. Indofood tahun 2016 diukur dari Cash ratio menunjukkan angka sebesar 132,42\%. Ratio $132,42 \%$ memenuhi kriteria rule of thumb yaitu $100 \%$ atau $1: 1$. Ratio ini menunjukkan bahwa setiap Rupiah Utang lancar dibayar dengan Rp1,3242 aktiva lancar tanpa neggunakan nilai persediaan dan piutang. Hal ini membuktikan bahwa PT.Indofood mampu melunasi kewajiban jangka pendeknya pada tahun 2016. Temuan ini mendukung hipotesis penelitian bahwa Likuiditas PT.Indofood dinilai dari aspek Cash ratio pada tahun 2016 memenuhi kriteria rule of thumb. PT. Indofood dikatakan Likuid.

Pertumbuhan Likuiditas dilihat dari Current Ratio pada tahun 2016 sebesar 3,47\%. Hal ini menunjukkan bahwa perusahaan mampu meningkatkan likuiditasnya sebesar 3,47\%. PT Indofood pada tahun 2016 lebih likuid dibandingkan dengan kemampuan PT. Indofood pada tahun 2015.

Pertumbuhan Likuiditas dilihat dari Quick Ratio pada tahun 2016 sebesar $1,3 \%$. Hal ini menunjukkan bahwa perusahaan mampu meningkatkan likuiditasnya sebesar 1,3\%. PT Indofood pada tahun 2016 lebih likuid dibandingkan dengan kemampuan PT. Indofood pada tahun 2015.

Pertumbuhan Likuiditas dilihat dari Cash Ratio pada tahun 2016 sebesar $-1,275 \%$. Hal ini menunjukkan bahwa perusahaan mengalami penurunan likuiditasnya sebesar $1,3 \%$. PT Indofood pada tahun 2016 mengalami penurunan kas dan setara kas dibandingkan dengan kemampuan kas dan setara kas PT. Indofood pada tahun 2015.

\section{KESIMPULAN DAN SARAN}

\section{Kesimpulan}

Berdasarkan hasil analisis dan pembahasan disimpulkan bahwa PT. Indofood pada tahun 2015 dan tahun 2016 mampu memenuhi kewajiban jangka pendek yang segera ditagih atau segera jatuh tempo. Current ratio PT Indofood memenuhi kriteria likuiditas dari aspek rule of thumb Current ratio sebesar $200 \%$ atau 2:1, sehingga hipotesis penelitian ini diterima.

PT. Indofood pada tahun 2015 dan tahun 2016 mampu memenuhi kewajiban jangka pendek yang segera 
ditagih atau segera jatuh tempo diukur dari Quick Ratio atau Acid Test Ratio. Quick ratio PT Indofood memenuhi kriteria likuiditas dari aspek rule of thumb Quickt Ratio sebesar 100\% atau $1: 1$, sehingga hipotesis penelitian ini diterima.

PT. Indofood pada tahun 2015 dan tahun 2016 mampu memenuhi kewajiban jangka pendek yang segera ditagih atau segera jatuh tempo diukur dari Cash Ratio. Cash Ratio PT Indofood memenuhi kriteria likuiditas dari aspek rule of thumb Cash Ratio sebesar $100 \%$ atau 1:1, sehingga hipotesis penelitian ini diterima.

PT. Indofood pada tahun 2016 mengalami Pertumbuhan Likuiditas dari Aspek Current Ratio dibandingkan dengan tahun 2015 yang mendukung hipotesis penelitin ini.

Pertumbuhan Likuiditas

PT.Indofood

dari aspek Quick ratio pada tahun 2016 dibandingkan dengan tahun 2015 yang mendukung hipotesis penelitian ini.

PT. Indofood mengalami pertumbuhan likuiditas dari aspek Cash Ratio yang menurun pada tahun 2016 dibandingkan dengan keadaan pada tahun 2015, sehingga hipotesis penelitian ini ditolak.

\section{Saran}

Berdasarkan kesimpulan dan keterbatasan penelitian ini disarankan kepada peneliti yang akan datang untuk menambah data penelitian(5-10 tahun) dan menggunakan analisis likuiditas maupun solvabilitas dalam menilai kemampuan perusahaan dalam memenuhi kewajiban jangka pendek maupun kewajiban jangka

panjang.

\section{DAFTAR PUSTAKA}

Bernstein , Leopold A. 1974. Financial Statement Analysis: theory,application and interpretation.Homewood: Illinois.

Fahmi, Irham. 2012. Analisis Laporan Keuangan. Cetakan Kedua. Alfabeta: Bandung

Munawir, S. 2004. Analisa Laporan Keuangan, Edisi keempat. Liberty: Yogyakarta

Riyanto, Bambang. 2001. Dasar-dasar Pembelanjaan Perusahaan. BPFE Gajah Mada:Yogyakarta

Riyanto,Bambang. 1978. Dasar-dasar Pembelanjaan Perusahaan. Yayasan Penerbit Gajah Mada: Yogyakarta

Tunggal. 2000. Pedoman pokok operasional Auditing. Harvarindo: Jakarta 